\title{
TEACHING READING COMPREHENSION BY USING SOME METHODS IN SENIOR HIGH SCHOOLS
}

\author{
Sopian Saori \\ English Lecturer, Sekolah Tinggi Ilmu Ekonomi (STIE AMM) Mataram \\ Corresponding Author Email: tsaurisofiyan@gmail.com
}

\begin{tabular}{l}
\hline \hline Article Info \\
\hline Article History \\
Received: December 2021 \\
Revised: January 2022 \\
Published: January 2022 \\
\hline Keywords \\
Teaching Reading; \\
Reading methods; \\
Reading comprehension;
\end{tabular}

\begin{abstract}
The study aimed to figure out the methods used by English teachers in teaching reading comprehension and how they applied them. The main purpose of the study was to describe the methods used by english teachers and reveal the strength and weakness of the methods. This research was a descriptive qualitative research. The design of the study was a case study. The participants of the research were two English teachers who teach in the second grade of senior high schools. Each English teacher had eight meetings that observed by the researcher. To collect the data, there were research instruments: observation, document analysys checklist and interview. They were used to find out the method used and how the English teachers applied them in teaching reading comprehension. The result of the study showed that both teachers used almost the same methods such as, grammar-translation method, scaffolding, and mind mapping. The difference was in the step of the implementation. In addition, the findings showed that the most appropriate method in teaching reading comprehension was the grammar-translation method since it helped students comprehend the text. There were several students who still found it hard to understand the materials of the lessons. Teachers were supposed to make sure that all students have understood the whole text or not and they should observe the students' situation and needs so that the teaching and learning process can run well and use better methods of teaching.
\end{abstract}

How to cite: Sauri, S. (2022). Teaching reading comprehension by using some methods in senior high schools, JOLLT Journal of Languages and Language Teaching, 10(1), pp. 66-75. DOI: https://doi.org/10.33394/jollt.v\%vi\%i.4638

\section{INTRODUCTION}

Reading skills are essential for English students to develop vocabulary, phrases, and grammatical patterns (Novita, 2018; Nerim, 2020). Reading texts coming from foreign language is different from texts from second language (Lail, 2019). English has become an international language and is used almost by all countries in the world. Obviously, it is important for all students to learn English in every level, including reading comprehension. Reading has become a part of compulsory subjects in many countries. In Indonesia, English is taught as a foreign language, and it becomes part of the school curriculum (Lail, 2019; Hidayat, 2017). It is a vital tool for the learners in the global era who wish to communicate easily across nationalities for many years to come. Therefore, students should master four language skills such as listening, reading, speaking, and writing (Haerazi et al., 2019). These four language skills cannot be separated, they are linked to each other and related to receptive and productive skills (Harmer, 2002).

Among the four skills in English, reading assists people to not only get access to more language input and obtain more knowledge concerning the world (Azis et al., 2019). It is the prominent method for learning new information and can provide new ways of perceiving the world and transforming the world (Arndt \& Woore, 2018). It is in line with Hidayat (2017) who states reading is essential activities for independent obtaining information from other 
countries for EFL students. Even though most of people learn to speak before they learn to read or write, most people have more needs and chances to read than to speak in learning a second and foreign language (Grabe and Stoller, 2001; Goodman, 1986; in Hsu, 2010).

Reading is one of the ways to get knowledge and information. Besides, the readers especially for students need to collect and learn new words or phrases from the text they read. Moreover, students can spare their time in a good way to gain information, knowledge, vocabulary, and improve their ability in English. According to Dean (2013) reading is more than seeing words clearly, more than pronouncing printed words correctly and more than recognizing the meaning of isolated words. It requires you to think and feel. It is not just looking and pronouncing words in the text but comprehending all the components of a text. In conclusion, the goal of reading is comprehending and gaining the meaning and information of the written text.

Teaching reading help students read English texts either for their career, study purposes, cognitive development, or simply for pleasure (Par, 2018; Harmer, 1998). It receives special attention. There are a number of reasons for this. First, many foreign language students often have reading as one of their most important goals. They want to be able to read for information and pleasure, for their career, for study purposes and for their future (Par, 2018). Second, written texts serve various pedagogical purposes. It provides good models for reading skills, and provides opportunities to introduce new topics, to stimulate discussion and to study language such as vocabulary, grammar and idioms (Haerazi et al., 2019; Montero, 2019; Richard and Renandya, 2002).

There are some principles of teaching reading. First, reading is an active skill. It means that reading is an incredibly active occupation (Richard \& Renandya, 2002). To do it successfully, the readers have to understand what the words mean, see the pictures the words painting, understand the arguments, and work out with them. If the readers do not do these things and she only just scratch the surface of the text and forget it, he will do not have the comprehension of it (Montero, 2019). Second, students need to be involved in what they are reading. As with everything else in lessons, students who are not engaged with the reading text not actively interested in what they are doing-are less likely to benefit from it. When they are really fired up with the topic or the task, they can get much more from what is in front of them (Nerim, 2020; Richard \& Renandya, 2002).

The last is good teachers exploit reading texts to the full. Any reading text is full of sentences, words, ideas, descriptions etc. It does not make sense just to get students to read it and then drop it to move on to something else. Good teachers integrate the reading text into interesting class sequences, using the topic for discussion and further tasks, studying the language and later activation (Pachina, 2020). The development of a positive attitude toward reading means progressing in confidence in his or her own ability as a reader. Ideally, students should experience success regularly and approach reading confidently, with a spirit, rather than avoiding it because it is painful and frustrating. Sadoski (2004: 48) mentions several characteristics of attitudes toward reading as follows.

\section{Positive Attitude}

Success

Confidence

Satisfaction

Acceptance

Self-esteem

\section{Negative Attitude}

Failure

Insecurity

Frustration

Stigmatization

Shame

Readers who find it difficult with reading and who were banished to the lowest reading group in school can attest to the negative attitude and make them feel failure and 
stigmatization. Learning to read is not simple. It is particularly vexing for some, and it is a hard work for nearly everyone. Experiencing success is important in early reading, but the development of positive attitudes reappears as a goal every time a reader is exposed to a new subject with its own vocabulary, symbol system, or discourse structures (Sadoski, 2004: 48).

The second goal in affective domain is developing personal interests and tastes in reading. Having a positive attitude is not enough. Lifelong readers choose to pursue their life interests through reading, at least in part, and in doing so they develop value judgments about what they read (Sadoski, 2004: 48). While in the cognitive domain, there are two goals that cover the utilitarian aspects of reading and the development of the mental skills that allow a reader to continue to mature as a good reader. The first is developing the use of reading as a tool to solve problems. Reading helps us to solve a broad array of personal and social problems in a complex, literate world. The print text is everywhere like memos and menus, candy wrappers and constitutions, bills and bumper stickers, cereal boxes and serial numbers, obituaries and optical charts, resumes and rest room doors (Sadoski, 2004: 51).

Reading is a way to navigate in a literate realm. It helps the readers to get from point A to point $\mathrm{B}$, whether these points are as close as connected websites on the Internet or as far as the journey from ignorant obscurity to educated influence. It is a way to deal with everyday problems where printed language is a feasible or requisite solution (Sadoski, 2004: 52). Two aspects of using reading as a tool to address large-scale social problems can be summarized. One aspect is educational reading. One mission of education is to transmit the knowledge base of civilization to new generations and increase that knowledge base and improve life. Another aspect of the utilitarian goal of reading is emancipation. Literacy is a means to liberate the mind and the spirit. Reading can free individuals or societies from oppression and dogma (Sadoski, 2004: 52-53).

The second is developing the fundamental competencies of reading at succeeding higher levels of independence. When the fundamental competencies of reading have been taught and learned, the reader is equipped to pursue reading as a continuing, lifelong endeavor. In line with this reasearch, many previous studies discussed about teachers strategies and methods in teaching reading comprehension. The first study conducted by Souhila (2014). She found that students had some difficulties in approaching reading strategies task. It confirmed that reading is a challenging and complex skill because students showed that they have a great awareness of reading, but unfortunately they have lacked some reading strategies. The result showed that there was a strong relationship between the students' knowledge (whether linguistic or background) and their success in applying strategies of reading about the text (whether general or specific).

Another research from Almasri and Alshumaimeri (2016) found that the performance of the students in the control and the experimental group improved significantly in reading comprehension scores. However, the strongly significant differences occurring in the experimental group's post-test comprehension performance when compared to the pre-test indicate that using Web-Quest can improve students' reading comprehension performance. The authors suggest that the teacher's experience of the Web-Quest tool, and the challenges to its integration in the blended learning classroom, should be investigated further.

Dwiningtiyas et al (2020) also conducted a study entitled Teachers' Strategy in Teaching Reading Comprehension. They found that teachers used several strategies in teaching reading comprehension. The strategies were brainstorming, reading aloud, and asking for specific information. They were encouraging dictionaries, reading aloud, rereading for checking comprehension, evaluating comprehension in particular tasks, and asking questions for specific information. Both teachers applied and combined the strategies divided into three stages of teaching reading comprehension. The stages were pre-reading stage, while reading stage, and post reading stage. The strategies applied were very effective in teaching 
reading comprehension in that school. It was proven by the students' motivation, students' attention, and teachers' ease in teaching and learning process.

Based on these relevant studies, the research focused on conducting a research which aimed to find out what the methods that are used by teachers in teaching reading comprehension. One main reason for conducting this research because there were just few studies discuss about that topic since that teaching reading method is essential for teaching reading. In addition, by conducting this topic, the researcher knew whether the teachers' methods are appropriate or not for the students in learning reading comprehension.

\section{RESEARCH METHOD}

The study belongs to qualitative research. It focus on studying social phenomena and on giving voice to the feelings and perceptions of the participants under study. It is based on the belief that knowledge is derived from the social setting and that understanding social knowledge is a legitimate scientific process. The researcher collects open-ended emerging data with the primary intent of developing themes from the data. This study used qualitative case study research to answer "what" questions. It used that method because it was also appropriate to the objectives of the research which focused on teachers' methods on teaching reading comprehension. The results of the research emphasized in the form of words and it was presented in narrative (Lodico, M. G et al, 2006)

The data taken from the interview answered the questions from the interviewer while the observation examined the correlation between the interviewee' answer and his/her action in class. In addition, the use of document analysis help the data more accurate and valid. The data was also recorded in a form of audio which later on would be examined and re-examined to minimize the mistakes in analyzing the data.

\section{Research Design}

The study used case study design. It is a form of qualitative research that endeavors to discover meaning, investigate processes, and gain insight into and in-depth understanding of an individual, group, or situation. The researcher would get close to a particular individual, group, school, classroom, program, or event. As in ethnographic research, the goal is to provide a richly detailed description (a thick description) of the situation, to capture the full complexity and uniqueness of the case information (Lodico, M. G et al, 2006). The research participants of this study were two English teachers at senior high schools in Gunungsari.

\section{Instruments}

An instrument is a tool for measuring, observing, or documenting data. It includes an interview, questionnaire, observation, and test. It used by researcher to collect the data. The result of the research were be better, more accurate, complete and systematic (Creswell, 2008). To generate findings in a systematic way, it is needed to have some instruments in the research. The instruments that used to collect the data from the research participants were interview, observation and document analysis.

\section{Data Analysis}

There were five steps to analyze the data: organizing the data, finding and organizing ideas and concepts, identifying patterns and connections within and between categories, and interpretation. Moreover, the researcher used triangulation method of the research. Data techniques were used: interview, observation and document analysis. Interview and observation correlated to each other, which meant the two data supported each other to make the conclusion. The document analysis made the study more accurate. The triangulation technique was used to get the most valid data. It attempts to provide 'a confluence of evidence that breeds credibility' (Eisner, 1991). By examining information collected through different 
methods, the researchers could corroborate findings across data sets and thus reduced the impact of potential biases that can exist in a single study (Lodico, M. G et al, 2006)..

\section{RESEARCH FINDINGS AND DISCUSSION Research Findings}

The main purpose of this research is giving the readers detail information about methods used by English teachers in teaching reading comprehension as well as the strength and weakness of the methods. There were three methods used by English teachers: grammar translation method, scaffloding, and mind mapping. Both of teacher A and B said that the grammar-translation method is a must since the students learnt a foreign language that was absolutely difficult to understand. The teachers asked what point they did not understand, and difficult words of the text. The teachers opened a question and answer section and discussion within the method which aimed to ask the students about the difficult words in such text. If they did not know the meaning, teacher explained the certain word by giving a movement such as clues or gestures to represent the meaning of the words. The students were enthusiastic in finding the meaning of the words and got the idea of the content of the text.

In addition, some of the students were also active and asked about what they found it difficult in the text. The teacher knew what materials that they would do in the teaching and learning process. Eventhough, there were few students who really quite and much didn't care about the materials to do. Based on the researcher observation, the activities done by teacher A and B were very impactful to the class conductivity and got the students' attention before they started to learn. Those activities then were followed by applying teaching methods in the main activity of teaching reading comprehension.

Both of teacher A and B used the grammar translation method to help students learning English easily and finding the meaning of the words or phrases from English into Indonesia. In translating the words, teachers used some gestures to represent the meaning of the text to stimulate the students' mind in guessing the words. That such method was really effective for students in comprehending the text and getting the information. In conclusion, the students can answer the questions of the reading text.

Grammar Translation Method is a suitable and helpful approach for the students who learn English as a foreign language. Teachers A and B used grammar translation method to help students converting the words from English into Indonesia so that they can easily grasp the passage and gain the information. From the observation, the writer saw that students can understand the whole text easily since they succeed in finding the meaning of difficult words that came up in the text. Besides, in translating the words teachers used some gestures to represent the meaning of the text to stimulate the students' mind in guessing the word. That such strategy was really effective for students in comprehending the text. So that they can easily answer the questions related to the text.

In addition, from the interview, the researcher have asked both teachers about the weakness of using grammar-translation method in teaching reading comprehension. The result showed that grammar-translation method is the only one method which has not any weaknesses from teachers' point of view.

\section{Scaffolding and Audio Visual Method}

Teacher A and B used scaffolding to help the learners learn English especially reading comprehension. They had similar thought in gaining students' attention but they did it in a different way. Teacher A created attractive-materials such as colorful pictures and videos related to the text which often about stories or past event in order to be showed and seen by students on LCD screen. This method aimed to gain the students' attention and build a concept of the material that are going to be taught in the classroom. On the other hand, 
teacher B also did scaffolding in different way. He began the class by giving a text or asking the students to open the textbook and read a certain text. The teacher would read the text at first, sentence by sentence then the students would repeat it. The objective of such activity was to make the students reading aloud the text so that they are accustomed to the vocabulary and the text. After reading the text, he also played a video in order to make the students more understand about what the topic is since it will be difficult to comprehend the text by only reading it.

From the data of interview and observation, scaffolding and audio visual methods had some strengths as well as weaknesses. First, when teacher A used scaffolding by showing pictures and videos all students were enthusiastic in watching the video, the pictures could attract students' attention. So, they were really enjoy the learning process through media such as power-point and video. On the other hand, when teacher asked the students some questions related to the video, not all students were active in answering those questions. Some of them understood the content of the text, but others just focused on images which showed up on screen. Besides, the position of the screen was not on the center of class, so the students who were sitting at the back corner of class could not see the power point clearly. It also had impact on their reading comprehension. When they read the text on the screen, they might miss some words, so their understanding of the content were less than others.

Besides, when teacher B used scaffolding by giving all the students printed text, they all seemed seriously read the text since the reason he gave the strategy was because she wanted the students got used to in reading procedure text. Reading the text made the students understood in pronouncing new vocabularies that came up in text, yet they might not pay attention to the content of the text. So when hhe asked some questions related to the text, students must read again the text in order to build the comprehension of the text.

\section{Mind Mapping}

Teacher $\mathrm{A}$ and $\mathrm{B}$ used mind mapping to make the students found it easy in understanding the text. Both of teacher A and B asked the students to read the text aloud. Then they gave a sheet of paper that contained a final assignment of mind mapping or story recipe. Teacher A divided the students into some group. Each group did the task by using mind mapping and finding the title of the text, problem, action, setting, characters, emotion, and conclusion. This method aimed to help students gain the information of the text. It made them work in group to solve the problems together.

Moreover, teacher B also did the same method as teacher A. He grouped the students in order to train their skill in performing the story of the text based on mind mapping or story recipe. Most of them demonstrated the story very well since they used the mind mapping as guidences. and retold it in the next meeting, and then he assessed their performance.

Using mind mapping in teaching reading comprehension can develop the students' ability in memorizing, brainstorming, learning, as well as creativity (Ingemann, 2008). To comprehend a text, the students must have background knowledge which is divided into two, background knowledge of the language and background knowledge of the world (Stanovich, 1991; McNamara, 1991, Silberstein, 1994). It means that through mind mapping the students were guided to develop their background knowledge of the text they are to read. They recall the existing knowledge and relate it with the text. By doing this they practice to brainstorming.

Moreover, Kaufman (2010) argued that "mind mapping is a useful technique to use while reading, since the non-linear format allows you to view the entirety of your notes at a glance, then easily place new information in the appropriate branch or make connections between ideas." This is in line with the theory of top-down process proposed by Nuttall 
(1996, cited in Brown, 2001:299). Top down is a process where the reader draws their own intelligence and experience to understand a text.

\section{Discussion}

The study described how the teachers used methods in teaching reading comprehension. What are the appropirate methods used to teach reading comprehension. Teachers had prepared the teaching materials such as lesson plan and textbook so that they know what to do in the classroom (Albiladi, 2018). They had known and mastered the methods to use and teach the students in order they found it easy to learn English. They had written step by step in teaching reading, start from the beginning of class by preparing students to pray, making a roll call, motivating, delivering the topics and assessing the students' comprehension and skill. In the classroom, they had done such activities they planned in advance, but sometimes they made an improvement.

The teachers had difference way to start the lesson. Teacher A showed the videos and pictures to introduce the topic, so that students could guess and grab the idea of the reading materials. It was supported by Ardnt \& Woore (2018) and Haerazi et al. (2019) who state videos and pictures can be utilized to encourage learners to pay attention to the teaching materials. Besides, the teacher began the class by giving a text or asking the students to open the textbook and read a certain text about reading. The teacher read the text first, sentence by sentence then the students repeated. The purpose of such activities were to make the students reading aloud and they were accustomed to the vocabulary and the text. It is also to build students' metacognitive skills in reading activities. It is aligned with Par (2018) and Huff \& Nietfeld (2019) who declare that learners can build their metacognition through monitoring what they have read in reading activities. Afterward, what he had done in continuing the teaching and learning process almost the same as with teacher B. Both teachers discussed the materials such as asking the difficult words in text which made students found it difficult to comprehend the text (Azis et al., 2019). Then, teachers translated those words together with the students. From these activities, the teachers tended to call the process as grammartranslation method.

Both teachers also asked the students if they did not understand the topics. They then explain more detail about what the text was and video told about, the function, generic structures and vocabulary. It is to help students have deep understanding of the text being read (Nerim, 2020; Hidayat, 2017). While explaining, teachers often gave several oral questions, and students gave the responds. At the end of the lesson, teachers gave written questions to the students so that the teachers knew the learners' understanding of the reading text. In addition, teacher A also told the students about types of questions in reading English text. By comprehending the types of questions, the students felt easier in answering the given tasks. After giving a lot of explanation and tasks related to the topics, teacher told and asked the students to practise their comprehension in a real life.

From the teachers' point of view, the combination of methods were very effective in order to have a good quality of teaching reading comprehension. They were feeling more comfortable in learning and understanding materials by using various methods. The findings also related with previous studies about teachers' strategies in teaching subjects. The first research was fconducted by Janatum (2013) who showed that the teachers had the difficulties to get the students' positive response of teaching and learning process. But then, the combination of various strategies or methods were really helped the teachers in gaining students' positive response and having a good quality of teaching English.

In line with the result of the study that the researcher did at one of senior high schools in Gunungsari, teachers had prepared and selected better methods in teaching comprehension. Hence, they did some activities in the classroom using three methods that they thought can 
build students' reading comprehension. What the researcher saw in the observation, teachers did not only pay attention on how students could understand the text well, but also how the students can use and apply them in real life which can be achieved if the students have really comprehend the content of the text. If the students have understood what the text is going to tell, they can implement that meaning and aim of the text, they can show or perform it in front of their friend and others (Grabe, 2009). Thus, all activities that had been done in class were connected one to another. The most important thing is students must achieve the reading comprehension if they want to train other skills such as speaking and writing. The result of the observation showed that the teachers had drilled the students to read and understand the text using three methods that the writer had mentioned. So, they get accustomed to reading English text and understanding the context of the text (Nation, 2009)

\section{CONCLUSION}

English teachers had used various strategies or methods in teaching reading comprehension. They did not only use one method to teach all students. The three methods that most used by English teachers were scaffolding and audio visual method, grammartranslation method and mind mapping. Moreover, the most appropriate method in teaching reading comprehension according to English teachers was grammar-translation method as it really helped students understanding the text easily. Second, mind mapping, it stimulated the students to work in group and trained their speaking skill which obtained from the result of reading and comprehending the text. Finally, scaffolding and audio-visual method since it really worked on attracting the students to focus on the materials and introduced them what kind of text they were going to learn.

The use of different methods is good in order to make students understand the materials due to the fact that students have difference ability, needs and background knowledge. By using various methods, the teachers would be helpful while teaching and learning process., Because the better method could help the students and otherwise. The result may be different from one students to another. It can be concluded that teachers should prepared and conducted the materials and methods as good as possible. Besides, the success and effectiveness of the methods can be achieved not only from the teachers but also from the students, since each students has difference background knowledge, needs, ability, the situation. So, it is difficult to know whether a particular method is effective or not. It has to be done in a long time to prove it. Moreover, for further researcher could ask and interview students' whether what teachers did in class related to teaching reading comprehension has made them understand the materials and text or not. Besides, post interview after doing an observation class is good to be done. This method can be used as reflection in teaching and learning process. So, for the next researcher can do this method to make the research more valid.

\section{ACKNOWLEDGEMENT}

I would like to give my deepest grattitude to my wife (Wahidaturrahmi) who provided insight and support that greatly assisted the research. I thank Sigit Ari Wijayanto M.M for his assistance with a particular technique, methodology, and Ertin Helmida for comments that greatly improved the manuscript. I would also like to show my gratitude to Faizatul Fajariah, M.M for sharing her pearls of wisdom with me during this research. 


\section{REFERENCES}

Albiladi, W. S. (2018). Exploring the Use of Written Authentic Materials in ESL Reading Classes: Benefits and Challenges. English Language Teaching, 12(1), 67. https://doi.org/10.5539/elt.v12n1p67

Almasri, Meshail M. \& Alshumaimeri, Yousif A. (2016). The effects of using web quests on reading comprehension performance of saudi efl students. Saudi Arabia: King Saud University.

Aziz, Z. A., Nasir, C., \& Ramazani, R. (2019). Applying Metacognitive Strategies in Comprehending English Reading Texts. Celt: A Journal of Culture, English Language Teaching \& Literature, 19(1), 138. https://doi.org/10.24167/celt.v19i1.1863

Arndt, H. L., \& Woore, R. (2018). Vocabulary learning from watching YouTube videos and reading blog posts. Language Learning and Technology, 22(3), 124-142.

Creswell, J. W. (2012). Educational Research: Planning, Conducting, and Evaluating Quantitative and Qualitative Research. ( $4^{\text {th }}$ ed.). Lincoln: University of Nebraska.

Dwiningtiyas, G. N., Sofyan, D., and Puspita, H. (2020). Teachers' Strategies In Teaching Reading Comprehension. Galuh University.

Grabe, W. (2009). Reading in a Second Language: Moving from Theory to Practice. New York: Cambridge University Press.

Grabe,W. and Stoller,FL. (2002). Teaching and Researching Reading. Harlow: Pearson Education Longman.

Haerazi, H., May Vikasari, R., \& Prayati, Z. (2019). The Use of Scientific-Based Approach in ELT Class to Improve Students' Achievement and Classroom Interaction. Register Journal, 12(2), 157-180. https://doi.org/10.18326/rgt.v12i2.157-180

Harmer, J. (1998). How to Teach English. Longman: Pearson Education Limited.

Harmer, J. (2002). The Practice of English Language Teaching. Longman: Pearson Education Limited.

Hidayat, N. (2017). Developing E-reading materials for students at grade sevent. JEES (Journal of English Educators Society), 2(1), 33. https://doi.org/10.21070/jees.v2i1.676

Hsu, C. Y. (2010). The Effect of Collaborative Strategic Reading on EFL Students' Reading Comprehension and Learning Interest. Taiwan: Unpublished Thesis.

Huff, J. D., \& Nietfeld, J. L. (2009). Using strategy instruction and confidence judgments to improve metacognitive monitoring. Metacognition and Learning, 4(2), 161-176. https://doi.org/10.1007/s11409-009-9042-8

Ingemann, M. (ny). The Power of mind mapping! Retrieved November 14, 2021, from http://www.FortuneWell.com

Kaufman, J. (ny). 3 Simple Techniques to Optimize Your Reading Comprehension and Retention. In The Personal MBA. Retrieved November 10, 2021, from http:// personalmba.com/3-simple-techniques-to-optimize-your-reading-omprehension- andretention/\#ixzz0hj7mdIy2

Lail, H. (2019). Answering Reading Texts on English Tryout Test Based on the 12Th Grade Students' Strategies At Sma Negeri1 Kuripan Lombok Barat. JOLLT Journal of Languages and Language Teaching, 7(1), 3. https://doi.org/10.33394/jollt.v7i1.1434

Lodico, M. G., Spaulding, D.T., and Voegtle, K. H. (2006). Methods in Educational Research (From Theory to Practice). San Francisco: Jossey Bass.

Montero Perez, M. (2019). Pre-learning vocabulary before viewing captioned video: an eyetracking study. Language Learning Journal, 47(4), 460-478. https://doi.org/10.1080/09571736.2019.1638623

Nation, I. S. P. (2009). Teaching ESL/EFL Reading and Writing. New York and London: Routledge Taylor and French Group. 
Nerim, N. (2020). Scrutinizing Directed Reading thinking activity (DRTA ) Strategy on Students' Reading Comprehension. JOLLT Languages and Language Teaching, 8(2), 128-138. https://doi.org/10.33394/jollt.v8i2.2284

Novita, D. (2018). Syndicate Learning: an Alternative Approach for Teaching Extensive Reading. Journal of Languages and Language Teaching, 6(1), 27. https://doi.org/10.33394/jollt.v6i1.810

Pachina, E. (2020). The Principles of Teaching Reading. Retrieved January, 2022 from https://www.teflcourse.net/blog/the-principles-of-teaching-reading-ittt-tefl-blog/

Par, L. (2018). The EFL students' critical reading skills across cognitive styles. JEELS, 5(1), 73-96. https://doi.org/https://doi.org/10.30762/jeels.v5i1.570

Rassaei, E. (2018). Computer-mediated textual and audio glosses, perceptual style and L2 vocabulary learning. Language Teaching Research, 22(6), 657-675. https://doi.org/10.1177/1362168817690183

Richard, J. C. and Renandya, W. A. 2002. Methodology in Language Teaching: An Anthology of Current Practice. New York: Cambridge University Press.

Sadoski, M. 2004 Conceptual Foundation of Teaching Reading. New York: The Guilford Press.

Silberstein, S. (1994). Techniques and Resources in teaching reading. Oxford University Press.

Souhila, Rouai. (2014). The use of reading strategies in improving reading comprehension. University Kasdi Merbah Ouargla.

Stanovich, K.E. (1991). Word Recognition: changing perspective. In Barr, R., et al (Eds.) Handbook of Research volume II (418-425). New York: Longman. 